\title{
TINJAUAN HUKUM ISLAM TERHADAP PELAKSANAAN PERKAWINAN ADAT JAWA
}

\author{
Muhammad Izzudin Shofwan \\ Ngazis Masturi \\ Universitas Nahdlatul Ulama Surakarta
}

\begin{abstract}
Abstrak
Penelitian bertujuan untuk mengetahui prosesi prosesi pelaksanaan perkawinan adat Jawa. Penelitian bersifat deskriptif. Hasil penelitian menunjukkan bahwa secara umum tata cara atau prosesi pelaksanaan perkawinan adat Jawa yang terjadi di Dukuh Pandanan Desa Soropaten Kecamatan Karanganom Kabupaten Klaten untuk memperkaya pandangan atau cakrawala penulis dalam mengabdi kehidupan bermasyarakat yang penuh dengan pengembangan kebudayaan serta adat istiadat yang masih berlaku di bumi nusantara ini, bahwa prosesi pelaksanaan perkawinan adat jawa terdiri dari tiga upacara yaitu: Upacara sebelum pelaksanaan ijab; Upacara pelaksanaan ijab; dan Upacara Kirab Pengantin.
\end{abstract}

Kata kunci: Perkawinan, Jawa, Prosesi

\begin{abstract}
The research aims to find out the procession of the implementation of customary Javanese marriage. Research is descriptive. The results showed that in general, the ordinance or parade of the performance of traditional Javanese marriages that occurred in Dukuh Pandanan Village Soropaten Karanganom District Klaten regency to enrich the view or horizon of the author in serving the community life full of cultural development and customs that still apply in this archipelago, that the procession of the implementation of customary Javanese marriage consists of three
\end{abstract}


ceremonies, namely; Ceremony before the performance of ijab; Ceremony of ijab; and the Ceremony of Kirab Pengantin.

Keywords: Marriage, Java, Procession

\section{A. PENDAHULUAN}

Undang-undang Nomor 1 Tahun 1974 Tentang Perkawinan Pasal 1 dinyatakan, "Perkawinan ialah ikatan lahir batin antara seorang pria dan seorang wanita sebagai suami istri dengan tujuan membentuk keluarga atau rumah tangga yang bahagia dan kekal berdasarkan Ketuhanan Yang Maha Esa".' Menurut ketentuan tersebut diatas perkawinan baru ada apabila dilakukan antara seorang pria dan seorang wanita, namun apabila dilakukan oleh dua orang pria saja (homo seksual) ataupun dua orang wanita saja (lesbian) maka hal tersebut tidak dapat dikatakan perkawinan.

Setiap orang yang melangsungkan perkawinan harus berlainan jenis yang sesuai dengan agama dan kepercayaanya serta dicatat dalam peraturan perundang-undangan yang berlaku. Perundang-undangan yang dimaksud adalah: Undang-undang Nomor 1 Tahun 1974 Tentang Perkawinan, Peraturan Pemerintah Nomor 9 Tahun 1975 Tentang Pelaksanaan UndangUndang RI Nomor 1 Tahun 1974, dan PMA Nomor 11 tahun 2007 Tentang Pencatatan Nikah.

Untuk melaksanakan perkawinan harus ada calon suami, calon istri, wali nikah, ijab dan Kabul. Wali nikah dalam perkawinan merupakan rukun yang harus dipenuhi bagi calon mempelai wanita yang bertindak untuk menikahkannya. Wali nikah terdiri dari wali nasab, dan wali hakim. Hubungan cinta kasih wanita dengan pria, setelah melalui proses dan pertimbangan, biasanya dimantapkan dalam sebuah tali perkawinan, hubungan dan hidup bersama secara resmi selaku suami istri dari segi hukum, agama dan adat. Di Jawa seperti juga di tempat lain, pada prinsipnya perkawinan terjadi karena keputusan dua insan yang saling jatuh cinta. Itu merupakan hal yang prinsip. Meski ada juga perkawinan yang terjadi karena dijodohkan orang tua yang terjadi dimasa lalu. Sementara orang-orang tua zaman dulu berkilah melalui pepatah cinta tumbuh karena terbiasa.

1 Zaenal Fatah dkk, Himpunan Peraturan Kepenghuluan, (Semarang: Kantor Wilayah Kementerian Agama Propinsi Jawa Tengah, 2013), hal. 18. 
Kehidupan kekeluargaan masih kuat, sebuah perkawinan tentu akan mempertemukan dua buah keluarga besar. Oleh karena itu, sesuai kebiasaan yang berlaku, kedua insan yang berkasih akan memberitahu keluarga masing-masing bahwa mereka telah menemukan pasangan yang cocok dan ideal.

Perkawinan merupakan suatu ikatan yang melahirkan keluarga sebagai salah satu unsur dalam kehidupan bermasyarakat dan bernegara, yang diatur oleh aturan hukum dalam hukum tertulis (hukum negara) maupun hukum tidak tertulis (hukum adat). Hukum negara yang mengatur mengenai masalah perkawinan adalah Undang-undang Nomor 1 Tahun 1974 tentang Perkawinan. Di lain pihak hukum adat yang mengatur mengenai perkawinan dari dulu hingga sekarang tidak berubah, yaitu hukum adat yang telah ada sejak jaman nenek moyang hingga sekarang ini yang merupakan hukum yang tidak tertulis.

Perkawinan merupakan suatu ikatan yang melahirkan keluarga sebagai salah satu unsur dalam kehidupan bermasyarakat dan bernegara, yang diatur oleh aturan hukum dalam hukum tertulis (hukum negara) maupun hukum tidak tertulis (hukum adat). Hukum negara yang mengatur mengenai masalah perkawinan adalah Undang-undang Nomor 1 Tahun 1974 tentang Perkawinan. Di lain pihak hukum adat yang mengatur mengenai perkawinan dari dulu hingga sekarang tidak berubah, yaitu hukum adat yang telah ada sejak jaman nenek moyang hingga sekarang ini yang merupakan hukum yang tidak tertulis. Perkawinan adalah "Ikatan lahir batin antara seorang pria dan seorang wanita sebagai suami istri dengan tujuan membentuk keluarga atau rumah tangga yang bahagia dan kekal berdasarkan Ketuhanan Yang Maha Esa".2 Dari perumusan tersebut dapat disimpulkan bahwa perkawinan itu mengandung beberapa unsur yaitu:

1. Ikatan lahir batin

2. Adanya seorang pria dan seorang wanita.

3. Membentuk keluarga bahagia.

4. Dalam waktu tak terbatas atau kekal.

${ }^{2}$ Undang-Undang Nomor 1 Tahun 1974 Pasal 1, Lihat Zaenal Fatah dkk, Himpunan Peraturan Kepenghuluan, (Semarang: Kantor Wilayah Kementerian Agama Propinsi Jawa Tengah, 2013), hal. 18. 


\section{Berdasarkan kepada Tuhan Yang Maha Esa.}

Bahwa perkawinan itu tidak cukup hanya dengan adanya suatu ikatan lahir atau ikatan batin saja, akan tetapi harus ada kedua unsur tersebut". ${ }^{3}$ Ikatan lahir yaitu ikatan yang dapat dilihat. Ikatan lahir ini berupa hubungan yang sah untuk hidup sebagai suami istri. Sebaliknya ikatan batin adalah ikatan yang tidak dapat dilihat. Tanpa adanya ikatan batin yang mendasari suatu perkawinan maka tidak akan ada artinya dan tidak ada jaminan perkawinan itu berlangsung secara utuh dan langgeng.

Ikatan lahir batin dalam suatu perkawinan merupakan faktor yang sangat penting karena perpaduan antara ikatan lahir dan ikatan batin akan menjadi fondasi yang kuat dalam membentuk dan membina keluarga yang bahagia dan kekal. Kompilasi Hukum Islam menjelaskan pengertian perkawinan adalah "Aqad yang sangat kuat atau mitsaqan ghalidzan untuk mentaati perintah Allah dan melaksanakannya merupakan ibadah". Pengertian perkawinan menurut hukum Islam adalah Nikah.

Nikah adalah suatu perjanjian atau aqad (ijab dan qabul) antara seorang laki-laki dan perempuan untuk menghalalkan hubungan badaniyah sebagaimana suami istri yang sah yang mengandung syarat-syarat dan rukun-rukun yang ditentukan oleh syariat agama Islams dan peraturan perundang-undangan. Nikah yaitu melakukan suatu aqad atau perjanjian untuk mengikatkan diri antara seorang laki-laki dan seorang wanita untuk menghalalkan hubungan kelamin antara kedua belah pihak, dengan dasar sukarela dan keridhoan kedua belah pihak untuk mewujudkan suatu kebahagiaan hidup berkeluarga yang diliputi rasa kasih sayang dan ketentraman dengan cara-cara yang diridhoi oleh Allah.

Pengertian perkawinan Menurut Kompilasi Hukum Islam dan Menurut Hukum Islam tersebut dapat dijelaskan bahwa perkawinan adalah ibadah, termasuk dalam rangka mentaati agama (Sunnatullah dan Sunnah Nabi Muhammad SAW). Didalam pengertian tersebut dikatakan bahwa

\footnotetext{
${ }^{3}$ Soenaryo, Hukum Adat II, (Surakarta: Buku Pegangan Kuliah Fakultas Hukum Universitas Sebelas Maret, 1993), hal. 19.

${ }^{4}$ Intruksi Presiden RI Nomor 1 Tahun 1991, Kompilasi Hukum Islam Di Indonesia, (Jakarta: Departemen Agama RI, 2000), hal. 14.

${ }^{5}$ Asrorun Ni'am Sholeh, Fatwa-Fatwa Masalah Pernikahan dan Keluarga, (Jakarta: elSAS, 2008), Cet. I, hal. 3.

${ }^{6}$ Ahmad Azhar Basyir, Hukum Perkawinan Islam, (Yogyakarta : Fakultas Hukum Universitas Islam Indonesia, 1977), hal. 10.
} 
pernikahan merupakan suatu perjanjian atau aqad, perjanjian yang sangat kuat atau mitsaqan ghalidzan untuk membentuk keluarga antara seorang pria dengan seorang wanita menjadi suami istri yang sah. "Perkawinan itu tidak hanya sebagai suatu perjanjian biasa melainkan suatu perjanjian suci dimana kedua belah pihak dihubungkan menjadi pasangan suami istri.

Tata cara pelaksanaan perkawinan atau kehendak nikah ${ }^{8}$ diatur dengan Undang-undang Nomor 1 Tahun 1974 tentang Perkawinan, Peraturan Pemerintah Nomor 9 Tahun 1975 tentang Pelaksanaan Undangundang Nomor 1 Tahun 1974, Peraturan Menteri Agama Nomor 11 Tahun 2007 tentang Pencatatan Nikah.

Pemberitahuan kehendak nikah dilakukan sekurang-kurangnya 10 (sepuluh) hari kerja sebelum perkawinan dilangsungkan. Pengecualian terhadap jangka waktu tersebut disebabkan sesuatu alasan yang penting dapat diberikan dispensasi oleh Camat atas nama Bupati. ${ }^{9}$ Kehendak nikah dilakukan secara tertulis dengan mengisi formulir pemberitahuan dan dilengkapi persyaratan sebagai berikut:

1. Surat keterangan untuk nikah dari kepala desa/ lurah atau nama lainnya (N 1)

2. Kutipan akta kelahiran atau surat kenal lahir, atau surat keterangan asal usul calon mempelai dari kepala desa/ lurah atau nama lainnya (N 2)

3. Persetujuan kedua calon mempelai (N 3)

4. Surat keterangan tentang orang tua (ibu dan ayah) dari kepala desa/ pejabat setingkat ( $\mathrm{N}$ 4)

5. Izin tertulis orang tua atau wali bagi calon mempelai belum mencapai usia 21 tahun (N 5)

6. Izin dari pengadilan, dalam hal kedua orang tua atau walinya sebagaimana dimaksud poin 6 di atas tidak ada;

${ }^{7}$ Soemiyati, Hukum Perkawinan Islam dan Undang-Undang Perkawinan (Undang-Undang Nomor 1 Tahun 1974), (Yogyakarta, Liberty, 1982), hal. 12.

${ }^{8}$ Hasil wawancara dengan Kepala Kantor Urusan Agama Kecamatan Sambi dan Staf pada tanggal 14 nopember 2014.

${ }^{9}$ Peraturan Pemerintah RI Nomor 9 Tahun 1975, Lihat Zaenal Fatah dkk, Himpunan Peraturan Kepenghuluan, (Semarang: Kantor Wilayah Kementerian Agama Propinsi Jawa Tengah, 2013), hal. 47. 
7. Dispensasi dari pengadilan bagi calon suami yang belum mencapai umur 19 tahun dan bagi calon istri yang belum mencapai umur 16 tahun

8. Surat izin dari atasannya/kesatuannya jika calon mempelai anggota TNI/ POLRI

9. Putusan pengadilan berupa izin bagi suami yang hendak beristri lebih dari seorang

10. Kutipan buku pendaftaran talak/ buku pendaftaran cerai bagi mereka yang perceraiannya terjadi sebelum berlakunya Undang-undang Nomor 7 Tahun 1989 tentang Peradilan Agama

11. Akta kematian atau surat keterangan kematian suami/ istri dibuat oleh kepala desa/ lurah atau pejabat setingkat bagi janda/ duda (N 6)

12. Izin untuk menikah dari kedutaan/ kantor perwakilan negara bagi warga negara asing. ${ }^{10}$

Setelah pemberitahuan kehendak nikah disampaikan kepada pegawai pencatat nikah, maka pegawai pencatat nikah mengadakan pemeriksaan nikah. Pemeriksaan nikah dilakukan oleh PPN atau Penghulu atau Pembantu Pegawai Pencatat Nikah/ P3N terhadap calon suami, calon istri, dan wali nikah mengenai ada atau tidak adanya halangan untuk nikah menurut hukum Islam dan kelengkapan persyaratan sebagaimana tersebut diatas. Hasil pemeriksaan nikah ditulis dalam Berita Acara Pemeriksaan Nikah (model NB) ditandatangani oleh PPN atau Penghulu, calon suami, calon istri, wali nikah dan Pembantu Pegawi Pencatat Nikah.

Apabila calon suami, calon istri, dan/ atau wali nikah tidak dapat membaca/menulis maka penandatanganan dapat diganti dengan cap jempol tangan kiri. Apabila calon suami, calon istri dan wali nikah bertempat tinggal di luar wilayah kecamatan tempat pernikahan dilangsungkan, pemeriksaan dapat dilakukan oleh PPN di wilayah yang bersangkutan bertempat tinggal.

Hasil pemeriksaan nikah ternyata terdapat kekurangan persyaratan/ketentuan, maka PPN atau Penghulu harus memberitahukan

10 PMA RI Nomor 11 Tahun 2007, Lihat Zaenal Fatah dkk, Himpunan Peraturan Kepenghuluan, (Semarang: Kantor Wilayah Kementerian Agama Propinsi Jawa Tengah, 2013), hal. 77. 
kepada calon mempelai dan wali nikah atau wakilnya tentang kekurangan syarat/ketentuan tersebut. Dalam hal hasil pemeriksaan membuktikan bahwa syarat-syarat perkawinan tidak terpenuhi atau terdapat halangan untuk menikah, maka kehendak perkawinannya ditolak dan tidak dapat dilaksanakan. PPN memberitahukan penolakan itu kepada calon mempelai dan wali nikah atau wakilnya disertai alasan-alasan penolakannya. Calon mempelai atau wali nikah dapat mengajukan keberatan atas penolakan tersebut kepada Pengadilan Agama Kabupaten/ Kota. Apabila pengadilan memutuskan atau menetapkan bahwa pernikahan dapat dilaksanakan, maka PPN diharuskan mengizinkan pernikahan tersebut dilaksanakan.

Pemeriksaan membuktikan bahwa syarat-syarat dan rukun perkawinan terpenuhi, maka akad nikah dan pencatatan nikah dapat dilaksanakan. PPN mencatat peristiwa nikah dalam akta nikah. Akta nikah ditandatangani oleh suami, istri, wali nikah, saksi-saksi dan PPN. Buku nikah adalah sah apabila ditandatangani oleh PPN/ Kepala kantor Urusan agama. Buku nikah diberikan kepada suami dan istri segera setelah proses akad nikah selesai dilaksanakan.

\section{B. METODE PENELITIAN}

Penelitian bersifat deskriptif yaitu “jenis penelitian untuk memberikan data yang seteliti mungkin tentang manusia, keadaan atau gejala-gejala lainnya"." Pemilihan lokasi dilakukan di Dukuh Pandanan Desa Soropaten Kecamatan Karanganom Kabupaten Klaten. Pengumpulan data dalam penelitian penulis mulai berusaha untuk menarik kesimpulan berdasarkan semua hal bersama-sama dalam reduksi data dan sajian datanya tersebut. Apabila nantinya kesimpulan yang dihasilkan dirasakan masih kurang mantap menurut pertimbangan peneliti, karena masih adanya data yang belum tercakup dalam reduksi dan sajian datanya, maka peneliti akan menggali kembali data-data yang sudah terkumpul dari buku catatan khusus yang memuat data-data yang sudah terkumpul dari lapangan. Seandainya dari buku catatan lapangan tersebut ternyata tidak terdapat data yang diperlukan maka peneliti akan melakukan pengumpulan data kembali untuk

\footnotetext{
${ }^{11}$ Soerjono Soekanto, Pengantar Penelitian Hukum, (Jakarta: UII Press Jakarta, 1986), Cet. I, hal. 10
} 
mendapatkan data-data khusus atau data-data tambahan yang diperlukan untuk memantapkan hasil peneliti susun, maka sebelum diakhirinya proses pembuatan kesimpulan riset, peneliti akan melakukan kegiatan pendalaman data ke lapangan.

\section{HASIL DAN PEMBAHASAN}

Hukum Islam sangat menghargai dan menghormati serta mengikuti perkembangan jaman baik segi sosial, kebudayaan maupun adat kebiaasan suatu daerah maupun negara baik tata cara pelaksanaaan suatu prosesi perkawinan maupun kebiasan peringatan hari besar Islam. Di dalam pelaksanaan proses perkawinann adat jawa di Desa Soropaten Kecamatan karanganom Kabupaten klaten terdapat beberapa prosesi antara lain :

\section{Upacara sebelum Perkawinan}

Hubungan cinta kasih wanita dengan pria, setelah melalui proses dan pertimbangan, biasanya dimantapkan dalam sebuah tali perkawinan, hubungan dan hidup bersama secara resmi selaku suami istri dari segi hukum, agama dan adat. Di Jawa seperti juga ditempat lain, pada prinsipnya perkawinan terjadi karena keputusan dua insan yang saling jatuh cinta. Itu merupakan hal yang prinsip. Meski ada juga perkawinan yang terjadi karena dijodohkan orang tua yang terjadi dimasa lalu. Sementara orang-orang tua zaman dulu berkilah melalui pepatah: witing tresno jalaran soko kulino, artinya: cinta tumbuh karena terbiasa.

Di Jawa dimana kehidupan kekeluargaan masih kuat, sebuah perkawinan tentu akan mempertemukan dua buah keluarga besar. Oleh karena itu, sesuai kebiasaan yang berlaku, kedua insan yang berkasihan akan memberitahu keluarga masing-masing bahwa mereka telah menemukan pasangan yang cocok dan ideal untuk dijadikan suami/istrinya.

a. Bibit, Bebet, Bobot

Secara tradisional, pertimbangan penerimaan seorang calon menantu berdasarkan kepada bibit, bebet dan bobot. 
Bibit: artinya mempunyai latar belakang keturunan kehidupan keluarga yang baik.

Bebet: calon pengantin, terutama pria, mempunyai perilaku yang baik

Bobot: kedua calon pengantin adalah orang yang berkwalitas, bermental baik dan berpendidikan cukup.

b. Peningset (Tali Kasih)

Biasanya yang melamar adalah pihak calon pengantin pria. Pada masa lalu, orang tua calon pengantin pria mengutus salah seorang anggota keluarganya untuk meminang. Tetapi kini, untuk praktisnya orang tua pihak lelaki bisa langsung meminang kepada orang tua pihak wanita. Bila sudah diterima, langsung akan dibicarakan langkah-langkah selanjutnya sampai terjadinya upacara perkawinan.

c. Pemasangan Bleketepe dan Tarub

Tarub berasal dari singkatan akronim yaitu "ta" dan "rub" artinya singkatan dari murub. Artinya ditata supaya murub arti bahasa indonesia adalah diatur supaya bercahaya.

Sehari sebelum upacara perkawinan, rumah orang tua mempelai wanita dipasangi tarub dan bleketepe dipintu masuk halaman depan. Dibuat gapura yang dihiasi tarub yang terdiri dari berbagai tuwuhan, yaitu tanaman dan dedaunan yang punya arti simbolis.

d. Siraman

Siraman dari asal kata siram, artinya mandi. Sehari sebelum pernikahan, kedua calon pengantin disucikan dengan cara dimandikan yang disebut Upacara Siraman. Calon pengantin putri dimandikan dirumah orang tuanya, demikian juga calon mempelai pria juga dimandikan dirumah orang tuanya. Hal-hal yang perlu dipersiapkan untuk Siraman:

1) Persiapan tempat untuk siraman, apakah dilakukan dikamar mandi atau dihalaman rumah belakang atau samping. 
2) Daftar orang-orang yang akan ikut memandikan. Sesuai tradisi selain kedua orang tua temanten, eyang temanten, beberapa pinisepuh. Yang diundang untuk ikut memandikan adalah mereka yang sudah sepuh, sebaiknya sudah punya cucu dan punya reputasi kehidupan yang baik.

3) Sejumlah barang yang diperlukan seperti: tempat air, gayung, kursi, kembang setaman, kain, handuk, kendi dsb.

4) Sesaji untuk siraman, ada lebih dari sepuluh macam, diantaranya adalah seekor ayam jago.

5) Pihak keluarga pengantin putri mengirimkankan sebaskom air kepada pihak keluarga pengantin pria. Air itu disebut air suci perwitosari artinya sari kehidupan, yaitu air yang dicampur dengan beberapa macam bunga, yang ditaruh dalam wadah yang bagus, untuk dicampurkan dengan air yang untuk memandikan pengantin pria.

e. Midodareni

Pada upacara midodareni yang berlangsung dimalam hari sebelum Ijab dan Temu Manten/ Panggih di keesokkan harinya, kedua orang tua calon mempelai pria beserta calon mempelai pria, diantar oleh keluarga dekatnya, berkunjung kerumah orang tua calon mempelai putri. Calon mempelai putri setelah dirias dikamar pelaminan, nampak cantik sekali bagai widodari, bidadari, dewi dari kahyangan.

\section{Upacara pelaksanaan ijab /Akad nikah}

Akah nikah ialah pengesahan perkawinan pria dan wanita menurut agama yang dianutnya, akah nikah tidak mempengaruhi jalannya upacara adat perkawinan jawa. Pelaksanaan akad nikah bagi yang beragama Islam dapat dilaksanakan di rumah, masjid atau KUA yang sesuai dengan UU No 1/1974 tentang Perkawinan. Sesuai dengan syarat dan rukun hukum Islam atau UU Perkawinan yaitu:

a. Calon Mempelai Pria Dan Calon Mempelai Wanita,

b. Wali Nikah 


\section{c. Dua Orang Saksi \\ d. Akad Nikah}

Kini, warga Penghayat Kepercayaan terhadap Tuhan Yang Maha Esa, perkawinannya juga diakui sah oleh negara sesuai dengan Undang-undang Republik Indonesia Nomor 23 Tahun 2006 tentang Administrasi Kependudukan dan Peraturan Pemerintah Republik Indonesia Nomor 37 Tahun 2007 Tentang Pelaksanaan Undangundang Nomor 23 Tahun 2006 tentang Administrasi Kependudukan.

\section{Upacara Panggih atau Temu Pengantin.}

\section{a. Balangan suruh}

Kedua pengantin bertemu dan berhadapan langsung pada jarak sekitar dua atau tiga meter, keduanya berhenti dan dengan sigap saling melempar ikatan daun sirih yang diisi dengan kapur sirih dan diikat dengan benang. Ini yang disebut ritual balangan suruh.

Kedua pengantin dengan sungguh-sungguh saling melempar sambil tersenyum, diiringi kegembiraan semua pihak yang menyaksikan. Menurut kepercayaan kuno, daun sirih punya daya untuk mengusir roh jahat. Sehingga dengan saling melempar daun sirih, kedua pengantin adalah benar-benar pengantin sejati, bukan palsu.

b. Ritual Wiji Dadi

Pengantin pria menginjak sebuah telur ayam kampung hingga pecah dengan telapak kaki kanannya, kemudian kaki tersebut dibasuh oleh Pengantin putri dengan air kembang. Pralambangnya: rumah tangga yang dipimpin seorang suami yang bertanggungjawab dengan istri yang baik, tentu menghasilkan hal yang baik pula termasuk anak keturunan.

c. Ritual Kacar Kucur atau Tampa Kaya.

Sepasang pengantin dengan bergandengan dengan jari kecilnya berjalan menuju depan krobongan, tempat dimana upacara tampa kaya diadakan.Upacara kacar kucur ini menggambarkan: suami 
memberikan seluruh penghasilannya kepada istri. Dalam ritual ini suami memberikan kepada istri: kacang, kedelai, beras, jagung, nasi kuning, dlingo bengle, beberapa macam bunga dan uang logam dengan jumlah genap.Istri menerima dengan segenap hati dengan selembar kain putih yang ditaruh diatas selembar tikar tua yang diletakkan diatas pangkuannya. Artinya istri akan menjadi ibu rumah tangga yang baik dan berhati-hati.

\section{d. Ritual Dhahar Klimah atau Dhahar Kembul}

Dengan disaksikan orang tua pengantin putri dan kerabat dekat, sepasang pengantin makan bersama, saling menyuapi. Mempelai pria membuat tiga kepal nasi kuning dengan lauknya berupa telor goreng, tempe, kedelai, abon, ati ayam. Lalu ia menyuapkan kepada istrinya, sesudah itu ganti sang istri menyuapi suaminya, diakhiri dengan minum teh manis bersama. Ini melambangkan bahwa mulai saat ini keduanya akan mempergunakan dan menikmati bersama apa yang mereka miliki.

\section{e. Mertui atau Mapag Besan}

Kedua orang tua pengantin putri menjemput kedua orang tua pengantin pria didepan rumah (untuk perkawinan digedung menjemputnya didepan ruangan tempat berlangsungnya acara ritual) dan mempersilahkan mereka masuk rumah/ ruangan tempat upacara, selanjutnya mereka berjalan bersama menuju ketempat upacara. Ibu-ibu berjalan didepan, bapak-bapak mengiringi dari belakang. Kedua orang tua pengantin pria didudukkan sebelah kiri pengantin, orang tua pengantin putri duduk disebelah kanan Pengantin.

\section{f. Upacara Sungkeman}

Sepasang pengantin melakukan sungkem kepada kedua belah pihak orang tua. Mula-mula kepada orang tua pengantin wanita kemudian kepada orang tua pengantin pria. Sungkem adalah merupakan bentuk penghormatan tulus kepada orang tua dan pinisepuh. Pada waktu sungkem (menghormat dengan posisi jongkok, kedua telapak tangan menyembah dan mencium lutut yang di-sungkemi), keris yang dipakai pengantin pria dilepas dulu 
dan dipegangi oleh perias, sesudah selesai sungkem, keris dikenakan kembali.

Dari hasil pengamatan penulis tentang prosesi pelaksanaaan perkawinan adat jawa di desa Soropaten Kecamatan Karanganom Kabupaten Klaten bahwa prosesi perkawinan adat jawa memberikan sikap dan pelajaran budi luhur, perilaku serta budaya yang tinggi untuk membentuk karakter dan kepribadian bangsa. Analisis tersebut berdasarkan watak dan sikap masyarakat Desa Soropaten Kecamatan karanganom Kabupaten Klaten dalam kehidupan sehari hari, yang aman, damai, bersahaja dan penuh tanggung jawab.

\section{KESIMPULAN}

Perkawinan merupakan sunnatullah bagi manusia maupun makhluk lainnya dengan tujuan untuk melestarikan generasi yang akan datang dan kebahagian hidup, agar dalam perkawinan dapat diakui oleh syari'at agama Islam dan diakui oleh negara, serta diketahui oleh masyarakat, maka harus dicatat dalam sistem administrasi agar tidak terjadi pembauran garis keturunan. Hukum Islam atau 'urf secara umum tidak melanggar tata cara dan perkawinan adat jawa karena perkawinan tersebut selama masih melaksanakan syari'at dan rukun perkawinan hukum Islam.

Tata cara atau prosesi pelaksanaan perkawinan adat jawa yang terjadi Di Dukuh Pandanan Desa Soropaten Kecamatan Karanganom Kabupaten Klaten untuk memperkaya pandangan atau cakrawala penulis dalam mengabdi kehidupan bermasyarakat yang penuh dengan pengembangan kebudayaan serta adat istiadat yang masih berlaku di bumi Nusantara ini, bahwa prosesi pelaksanaan perkawinan adat jawa terdiri dari tiga upacara yaitu ;

1. Upacara sebelum pelaksanaan ijab

2. Upacara pelaksanaan ijab

3. Upacara kirab pengantin

Hukum Islam bersifat flesikbel dan tidak kaku terhadap masalah serta luwes dalam menerapkan hukum. Serta tata cara atau prosesi pelaksanaan 
perkawinan hukum adat di Jawa masih dalam tatanan yang tidak melanggar syari' at hukum Islam.

\section{REFERENSI}

Aep S Hamidin, Buku Pintar Adat Perkawinan Nusantara, Jakarta: Diva Press, 2012

Anwar, H. Moch. Risalah Nikah (Hukum Perkawinan Islam), Jakarta: Pustaka Amani, 1989.

Inpres RI Nomor I Tahun 1991, Kompilasi Hukum Islam Di Indonesia, Jakarta: Departemen Agama RI, 2000.

Kamil, Taufiq, Membina Keluarga Sakinah, Jakarta: Direktorat Jendral Bimbingan Masyarakt Islam Dan Penyelenggaraan haji, 2003

Nawawi, Hadar, Metode Penelitian Bidang Sosial, Yogyakarta: Gajah Mada University Press, 1986.

Poerwadarminta, WJS, Kamus Umum Bahasa Indonesia. Jakarta: Balai Pustaka, 1986.

Ramulyo, M. Idris, Hukum Perkawinan Islam (Suatu Analisis Dari Undangundang Nomor 1 Tahun 1974 Dan Kompilasi Hukum Islam), Jakarta: Bumi Aksara, 1996.

Soenarjo dkk, Alquran Dan Terjemahnya, Jakarta: Departemen Agama RI, 1971.

Sutopo, HB, Pengantar Penelitian Kualitatif, Surakarta: Litbang UNS, 1988.

Soekanto, Soerjono, Pengantar Penelitian Hukum, Jakarta: UII Press, 1986.

Soemiyati, Hukum Perkawinan Islam dan Undang-undang Perkawinan (Undang-undang Nomor 1 Tahun 1974), Yogyakarta: Liberty. 1982.

Soenaryo, Hukum Adat II, Surakarta: Buku Pegangan Kuliah Fakultas Hukum Universitas Sebelas Maret. 1993.

Thomas Wiyasa Bratawijaya, Upacara Perkawinan Adat Jawa, Jakarta :Pustaka Sinar Harapan, 2006 
ACADEMIA: Jurnal Ilmu Sosial dan Humaniora, Vol. 1 No 2 Februari 2019

Yunus, Mahmud, Hukum Perkawinan Dalam Islam, Jakarta: Hidakarya Agung, 1985. 